\title{
Acoustic emission method as a tool for the assessment of influence of the temperature variation on destructive processes created in early age concrete
}

\author{
Magdalena Bacharz ${ }^{1, *}$, Wiesław Trąmpczyński ${ }^{1}$, and Barbara Goszczyńska ${ }^{1}$ \\ ${ }^{1}$ Kielce University of Technology, Faculty of Civil Engineering and Architecture, \\ al. 1000-lecia Państwa Polskiego 7, 25-314 Kielce, Poland
}

\begin{abstract}
During the early age concrete treatment (curing and hardening) the damage process appears i.e., microcracks in the cement paste, propagation of internal microcracks, and formation of microcracks on the surface of concrete that affect concrete. It can be the serious source that initiate cracks that will propagate in the further loading stage, thereby affecting the overall strength and durability of structures. Hence, it is quite important to have a tool to identify the damage processes created up during the early age concrete treatment. The Identification of Active Damage Processes (IADP) acoustic emission method, modified to suit the tests on non-loaded concrete, was applied to determine and locate the damage processes that appears during the hardening conditions taking into account the temperature fluctuations on which construction structures are exposed (constant temperature of $22^{\circ} \mathrm{C}$ or cyclic temperature variations in the range $-5^{\circ} \mathrm{C} /+42^{\circ} \mathrm{C}$ ) in non-loaded concrete produced with basalt aggregate and blast furnace cement. It is shown that the modified IADP method, can be used to assess the influence of the temperature variation on damage process in early age non-loaded concrete. As an example, concrete produced with basalt aggregate and blast furnace cement was used.
\end{abstract}

\section{Introduction}

Curing is all of the efforts made after concrete mix placement and compaction to maintain the optimal moisture and temperature conditions and to prevent weather impacts. These efforts are necessary to ensure proper cement hydration and allow concrete structure to form. The curing process, especially that during the first days of concrete hardening, is a key factor in terms of long-term durability of concrete members. Moisture loss due to lack of curing will contribute to lower strength gain, higher permeability and absorption, higher plastic shrinkage and crack formation [1].

In addition to the concrete curing, variable climatic conditions, which can not be predicted or declared, are also important. For example, in 2017, the largest amplitude of extreme temperature values in Poland was $74.6^{\circ} \mathrm{C}$ [2]. Significant temperature changes can also be observed within a day. From 1971 to 1995 , in some regions of Poland, the daily temperature

\footnotetext{
* Corresponding author: mbacharz@tu.kielce.pl
} 
amplitude was up to $16^{\circ} \mathrm{C}$ [3]. A record daily amplitude $\left(56^{\circ} \mathrm{C}\right)$ was observed in the United States at Browning, when in 1916 the temperature decreased from $+7^{\circ} \mathrm{C}$ to $-49^{\circ} \mathrm{C}$ [4].

The exchange of heat and moisture of concrete with the environment and the hydration process of the cement cause unhomogenous volume changes of hardening concrete. These changes, often with significant values, cause thermal-shrinkage stresses that can cause cracking of structural elements.

Damage or destructive processes that occur in early age concrete, such as microcracks in the cement paste (including those at the grain boundaries) and their growth as well as microcracks nucleating and propagating on the concrete surface $[1,5,6]$ reduce the tightness of the concrete cover and expose reinforcement bars to adverse effects of aggressive factors, which, occasionally, may lead to final failure.

In view of the above, analysis and assessment of destructive processes occurring in concrete prior to it being put to service is of key importance.

Methods that allow observation of micro-cracks formed in the concrete are techniques based on image processing [7, 8]. A critical review of these methods and based on them analysis of crack detection in concrete was described in [9]. In [10] ability of used microscopy methods on their ability to show drying shrinkage microcracks on a specimen cross-section was tested. The main problems of these studies are to determine the time of occurrence of individual microcracks to determine location of damages and to determine which cracks appeared during sample preparation or examination. Moreover these methods interfere with the structure of the test material and have local character.

Therefore, in recent years, particularly non-destructive methods are used in structural diagnostics. Most of them [11-14] are based primarily on the detection of cracks in concrete without matching them to specific damage processes, thus making their progress impossible to trace or analyse. Continuous and real-time monitoring of the occurrence and development of damage in concrete is allowed by using methods based on recording of Acoustic Emission signals. In the case of non-loaded concrete, the individual parameters, i.e. the number of AE events and absolute energy are analysed. Most studies, e.g. [14-16], are based on the fact that a sudden increase in $\mathrm{AE}$ events is related to concrete failure. In these studies the researchers determine general reasons of these cracks, e.g. thermal or drying shrinkage cracks. There are no techniques, in available literature, that would allow an identification of cracks (microcracks in the cement paste, growth of microcracks as well as microcracks nucleating and propagating on the concrete surface) and tracking of destructive processes.

Therefore, the IADP (Identification of Active Destructive Processes) Acoustic Emission method was developed for identification and location of damage processes in prestressed [17] and reinforced concrete members [18-20].

In [21] it was demonstrated that the modified IADP method, can be used for identification and location of damage processes also in early age non-loaded concrete.

The main purpose of this study was to use AE method to analyze the effect of curing conditions (constant temperature of $22^{\circ} \mathrm{C}$ versus temperatures varied cyclically between $-5^{\circ} \mathrm{C}$ and $+42^{\circ} \mathrm{C}$ ) on number of the damage processes in the non-loaded concrete - microcracks in the cement paste, propagation of internal microcracks, and formation of microcracks on the surface of concrete - at the early stage of concrete hardening. It has an important practical meaning for evaluation of the curing processes as the early age damage can be the source of the damage development during the operational load. 


\section{IADP acoustic emission method}

The IADP method is based on a comparative analysis of acoustic emission (AE) signals from the damage processes recorded during the hardening cycle and the signals collected in the reference signal database [18].

Figure 1 shows a scheme of application of the method. A defect in a concrete specimen emits elastic waves which are received by acoustic sensors and converted to electric signals.

The signals are pre-amplified and recorded by the processor to be grouped and compared with those stored in the reference signal database for damage processes created earlier under laboratory conditions, and assigned to the corresponding classes of signals. It allows for damage identification and location.

The AE system consisted of 14-channel processor with MISTRAS software and PC for data storage analysis. Two AE piezoelectric sensors (Table 1) with a frequency range of $25-80 \mathrm{kHz}$ were mounted on each specimen. This was necessary to perform linear location of destructive processes. Sensors were placed on specimens with silicon grease as the coupling agent. The detected signals were amplified with a $40 \mathrm{~dB}$ gain amplifiers. To eliminate background noises signal detection threshold was set at a value of $35 \mathrm{~dB}$ moreover specimens were placed in an acoustically insulated chamber. Before each measurement calibration of AE sensors was performed. AE source was simulated using pencil-lead break (Hsu-Nielsen source). When an amplitude of $100 \mathrm{~dB}$ was recorded measurements were started. The measured signals (idealized one is shown schematically in Fig. 2) were characterized by 12 AE parameters: counts, counts to the peak amplitude, signal duration, signal rise time, signal amplitude, signal energy, signal strength, average effective voltage, absolute energy, average frequency, reverberation frequency and initiation frequency citation.

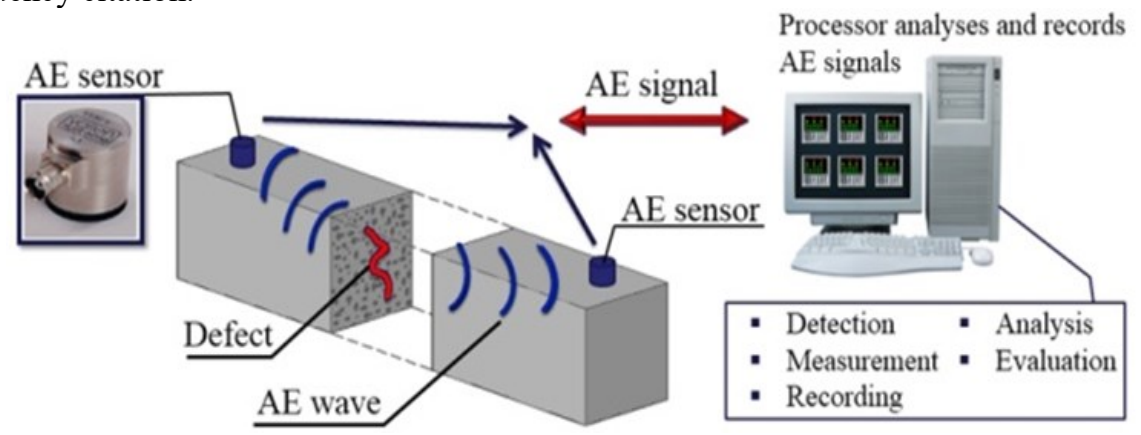

Fig. 1. Schematic representation of the IADP acoustic emission method.

The signals recorded by the processor were compared with those stored in the reference signal database for damage processes created earlier under laboratory conditions, and assigned to the corresponding classes of signals. Signals representing individual destructive processes selected using K-means algorithm, unsupervised method. The stages in the development of the signal database are described in [17]. 


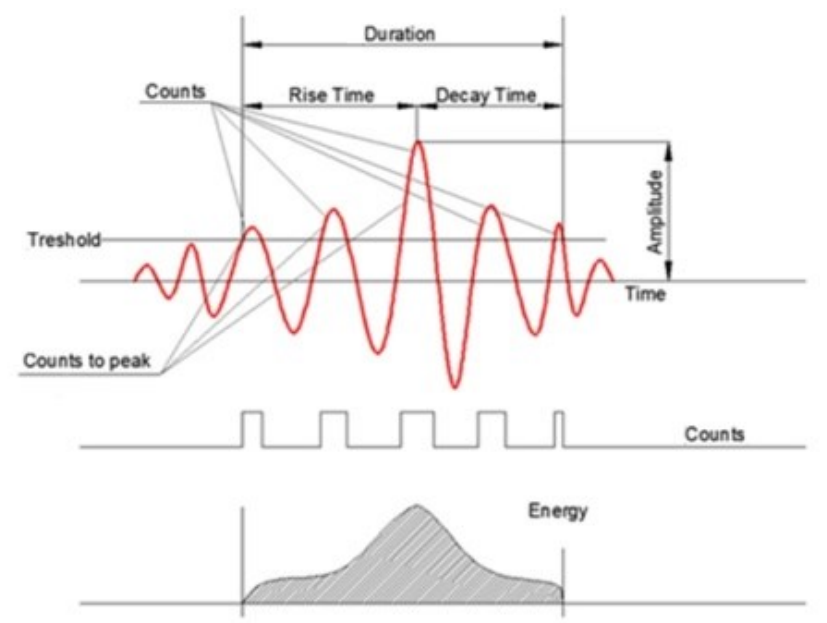

Fig. 2. Schematic representation of the IADP acoustic emission method.

The initial reference signal database, based on the collection of 12 AE signal parameters, comprises four signal classes, which, as described in $[18,21]$, correspond to the damage processes that occur in concrete during the curing period:

Class 1 - Damage process I - Initiation of microcracks in the cement paste (in the paste and at the grain boundaries)

Class 2 - Damage process II - Propagation of internal microcracks

Class 3 - Damage process III - Formation of microcracks on the surface of concrete

Class 4 - Damage process IV - Surface crack propagation.

In $[14,15]$ the authors verified the correctness of assigning AE signals to the damage processes listed above.

Table 1. VS30-V AE sensor parameters.

\begin{tabular}{|l|l|l|l|l|l|l|}
\hline $\begin{array}{l}\text { Frequency range } \\
\text { fPeak }[\mathrm{kHz}]\end{array}$ & $\begin{array}{l}\text { Operating } \\
\text { temperature } \\
{\left[{ }^{\circ} \mathrm{C}\right]}\end{array}$ & $\begin{array}{l}\text { Capacity } \\
{[\mathrm{pF}]}\end{array}$ & $\begin{array}{l}\text { Vibration @ } \\
\text { Sinus Sweep }\end{array}$ & $\begin{array}{l}\text { Size } \\
(\mathrm{DxH}) \\
{[\mathrm{mm}]}\end{array}$ & $\begin{array}{l}\text { Weight } \\
{[\mathrm{g}]}\end{array}$ & $\begin{array}{l}\text { Ingress } \\
\text { Protection } \\
\text { Rating }\end{array}$ \\
\hline 25 to 80 (flat) & -5 to +85 & 140 & $\begin{array}{l}2 \mathrm{Oct} / \mathrm{Min}, 5 \\
\text { to } 180 \mathrm{~Hz}, 40 \mathrm{~g}\end{array}$ & $\begin{array}{l}20.3 \mathrm{x} \\
37.0\end{array}$ & 69 & IP40 \\
\hline
\end{tabular}

\section{Testing procedure}

A total of 6 specimens (two concrete series of three specimens each) were tested. The specimens were $150 \times 150 \times 600 \mathrm{~mm}$ in size and were made of $\mathrm{C} 30 / 37$ without chemical admixtures (including plasticizer or air entraining agents). The concrete series (denoted by B5 and B6) were made with basalt aggregate from Górażdże mine and CEMIII/A 42,5N - HSR/NA from Małogoszcz cement plant.

Table 2. Chemical composition of used cements.

\begin{tabular}{|c|c|c|c|c|c|}
\hline Type of cement & $\mathrm{SO}_{3}[\%]$ & $\begin{array}{c}\mathrm{Cl}^{-} \\
{[\%]}\end{array}$ & $\begin{array}{c}\mathrm{Na}_{2} \mathrm{O}_{\mathrm{eq}} \\
{[\%]}\end{array}$ & $\begin{array}{c}\text { Density } \\
{\left[\mathrm{g} / \mathrm{cm}^{3}\right]}\end{array}$ & $\begin{array}{c}\text { Specific area } \\
{\left[\mathrm{cm}^{2} / \mathrm{g}\right]}\end{array}$ \\
\hline CEMIII/A 42.5N - HSR/NA & 2.69 & 0.066 & 0.81 & 2.97 & 4675 \\
\hline
\end{tabular}


Table 3. Mixture proportion of concrete specimens $\left[\mathrm{kg} / \mathrm{m}^{3}\right]$.

\begin{tabular}{|c|c|c|c|c|c|c|c|}
\hline \multirow[b]{2}{*}{ Symbol } & \multicolumn{2}{|c|}{ Basalt aggregate } & \multirow{2}{*}{$\begin{array}{c}\text { Sand } \\
0-2\end{array}$} & \multirow{2}{*}{$\begin{array}{c}\text { CEM III/A 42,5N } \\
\text { LH-HSR/NA }\end{array}$} & \multirow[b]{2}{*}{ Water } & \multicolumn{2}{|c|}{ Admixtures } \\
\hline & $2-8$ & $8-16$ & & & & $\begin{array}{c}\text { air entraining } \\
\text { agent }\end{array}$ & plasticizer \\
\hline B5, B6 & 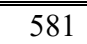 & 731 & 691 & 360 & 180 & 0 & 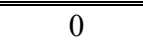 \\
\hline
\end{tabular}

The specimens were tested directly after having been removed from the moulds, without the initial curing in water. The B5 specimens were cured at a constant temperature of $22^{\circ} \mathrm{C}$, whereas the $\mathrm{B} 6$ specimens were subjected to cyclic temperature variations. Figure 3 shows the changes in temperature during 12-hour cycles of heating up to $+42^{\circ} \mathrm{C}$ and cooling to $-5^{\circ} \mathrm{C}$ for the first 14 days of testing.

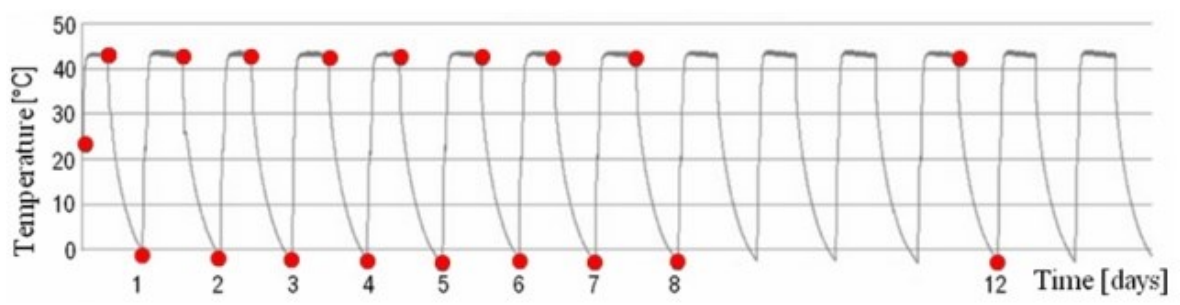

Fig. 3. Varying temperature distribution for the first 14-day monitoring period.

Prior to testing, two AE sensors were mounted on one side $35 \mathrm{~mm}$ from the top and bottom edge of each specimen, as shown in Figure 3a, b. The specimens so prepared were placed in the chamber designed to ensure assumed thermal and acoustic conditions.

During the study, the AE signals were measured and the damage processes (signal classes) were recorded during the 12-hour cycles in 1-8, 12, 16, 20, 24, 28, 38, 46 and 57 days.
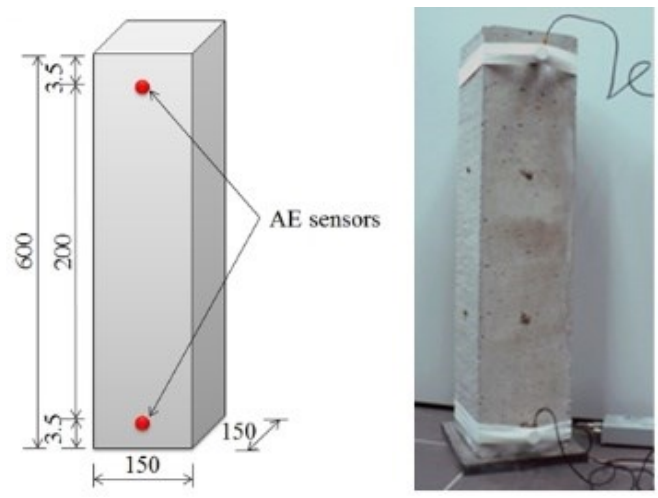

Fig. 4. Schematic diagram of AE sensors arrangement on the test specimen (dimensions in centimeters) and specimen during the study.

Humidity in the chamber was not controlled.

\section{Test results and their analysis}

To compare damage processes from the individual concrete series, the results obtained with the acoustic method, i.e. the AE signals (corresponding to damage processes) were averaged. The values from the six sensors mounted on the three specimens in the given series were added up and divided by the number of recording sensors. 


\subsection{Concrete B5 - no water curing after demoulding; hardening at constant temperature $22^{\circ} \mathrm{C} \pm 2^{\circ} \mathrm{C}$}

Figure 5 compiles the results in terms of the number of signals recorded in concrete series B5.

The largest number of signals, an average of 4084 signals corresponding to damage process I (initiation of microcracks in the cement paste) were recorded. During the first week of observations, the signals were the highest in number and then they decreased until day 28 to remain at a fixed level until the end of the test.

Only few signals corresponding to damage process II (propagation of internal microcracks) were recorded. Development of this process was observed only during the first 28 days.
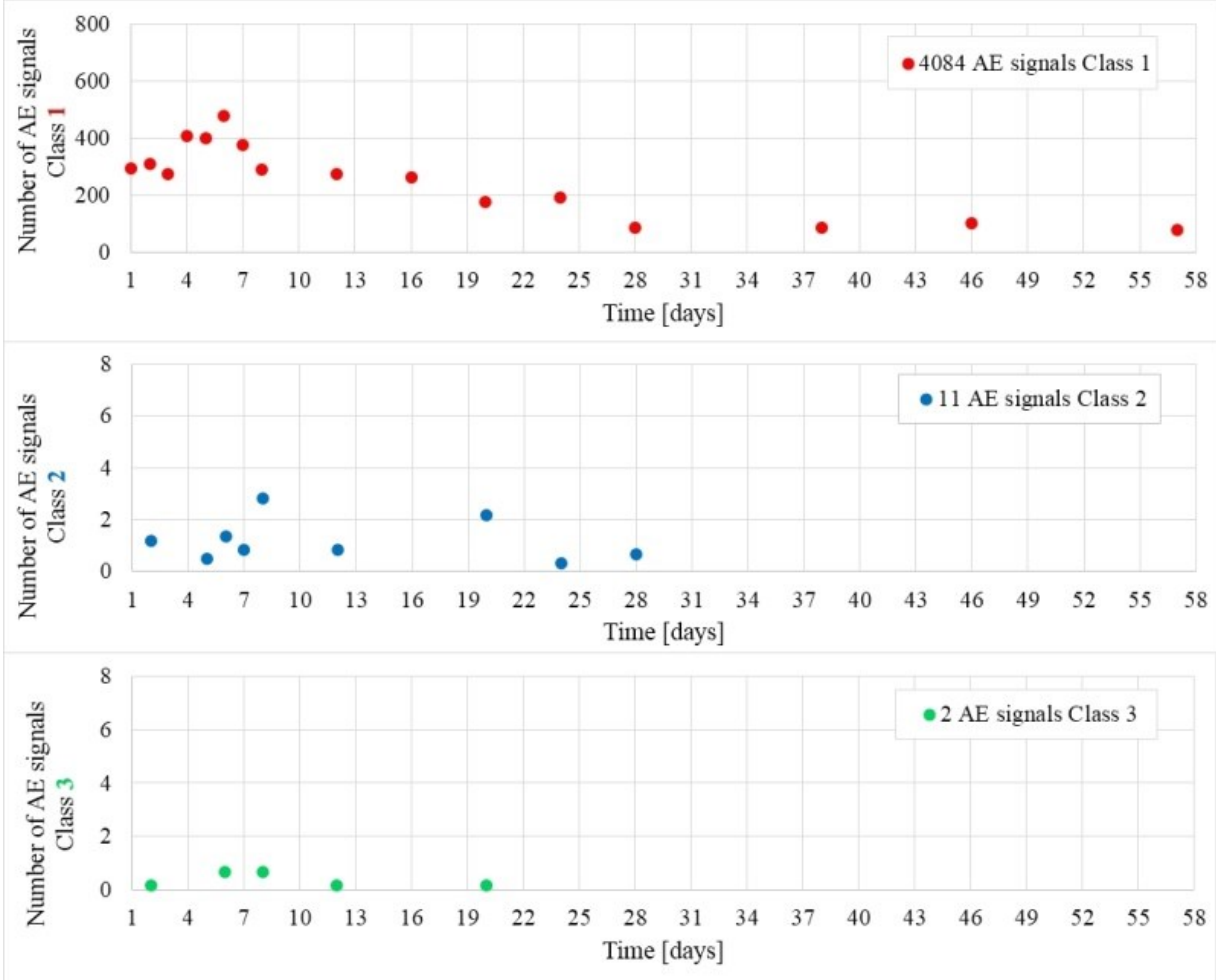

Fig. 5. Number of signals corresponding to damage process I, II, III recorded in series B5 specimens.

Up till day 20, single signals corresponding to damage process III (formation of microcracks on the surface of concrete) were detected, as shown in Figure 6.

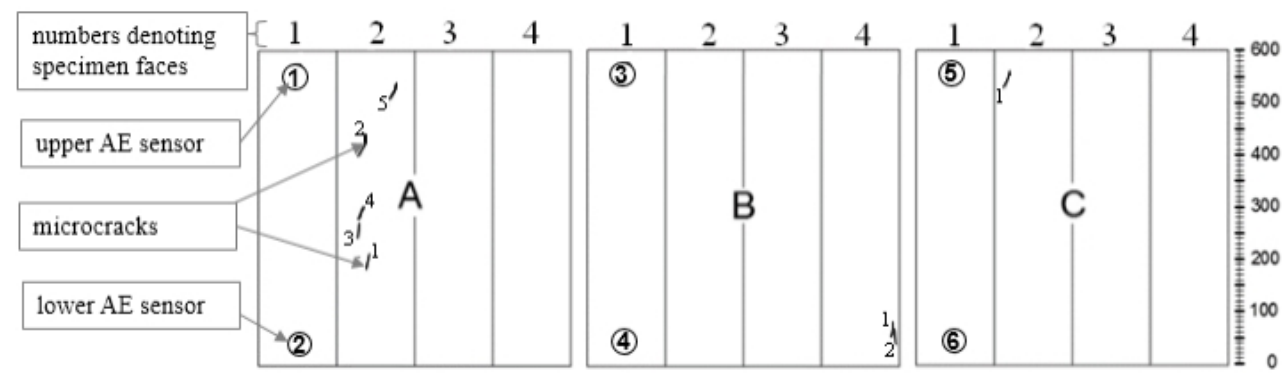

Fig. 6. Image of side surface microcracks, specimens A, B and C in the B5 series. 
The recorded AE signals Class 1 (destructive processes I) were compared with the measured deformations and loss of water in the B5 concrete samples (Fig.7). These values were obtained as mean values from three of B5 concrete samples.

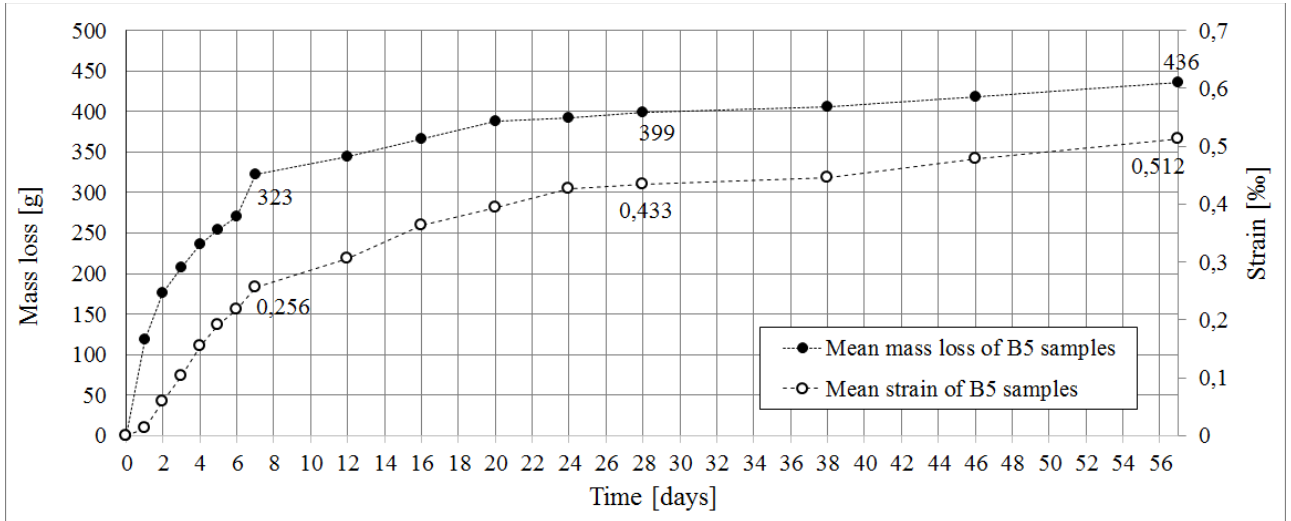

Fig. 7. Diagram of average mass loss and average strain in B5 concrete specimens (A, B, C).

In both graphs (Fig. 7) a similar course was observed during the study, which can be divided into three stages. The highest increase in strains was observed in the first week of the study (increase of the average value by $0.037 \%$ /day). From the $8^{\text {th }}$ to $28^{\text {th }}$ day of the study, the values of strains increased about $0.008 \%$ in day and after $28^{\text {th }}$ day by $0.003 \%$. Similarly the average mass loss was 46, 3.62, $1.28 \mathrm{~g}$ /day in particular intervals. The results summarized in Table 4 and compared with average number of destructive processes I.

Table 4. Average values measured in B5 concrete during the day in a particular stage of the study.

\begin{tabular}{|c|l|l|l|l|}
\hline $\begin{array}{c}\text { Concrete } \\
\text { series }\end{array}$ & $\begin{array}{l}\text { Tested parameter [average values measured } \\
\text { during a day] }\end{array}$ & $1-7$ days & $8-28$ days & $28-57$ days \\
\hline \multirow{2}{*}{ B5 } & Strain [\%o/day] & 0.037 & 0.008 & 0.003 \\
\cline { 2 - 5 } & Mass loss [g/day] & 46.00 & 3.62 & 1.28 \\
\hline
\end{tabular}




\subsection{Concrete B6 - no water curing after demoulding; hardening at varied cyclically temperature between $-5^{\circ} \mathrm{C}$ and $+42^{\circ} \mathrm{C}$}

Development of destructive processes I, II, III was recorded in concrete series B6, as shown in Figure 7.

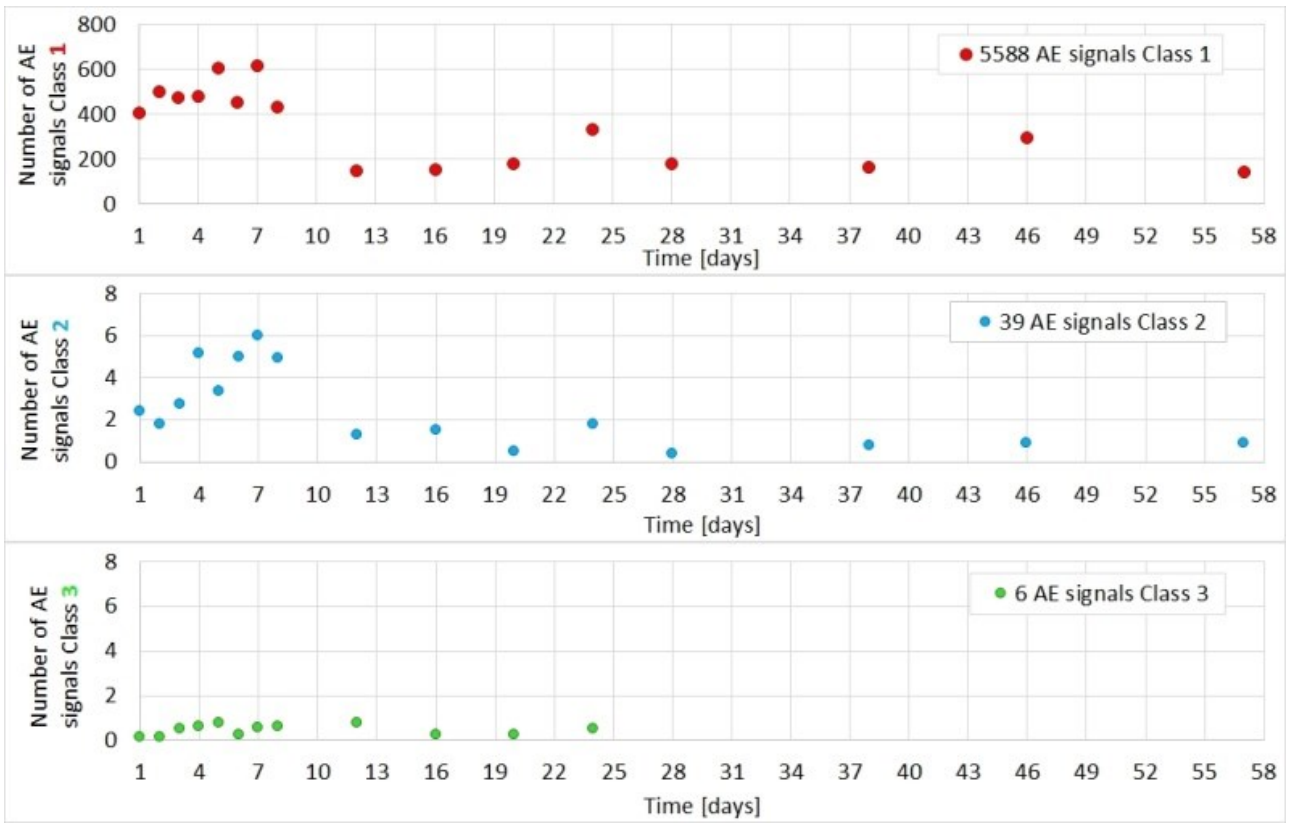

Fig. 8. Number of signals corresponding to damage process I, II and III recorded in series B6 specimens.

Most signals recorded (5588) were signals corresponding to the damage process I (initiation of microcracks in the cement paste).

The largest number of these processes were observed during the first week. Then, their number decreased dramatically. This processes were detected until the end of the test.

A total of 39 signals corresponding to damage process II (propagation of internal microcracks) were detected during the test. These processes did not fade out. The number of the signals, growing during the first week, decreased rapidly afterwards and remained at the fixed level until the end of the test.

The smallest number of signals corresponding to damage process III (formation of microcracks on the surface of concrete) were recorded. The image of side surface cracks of B6 specimens is shown in Figure 9.
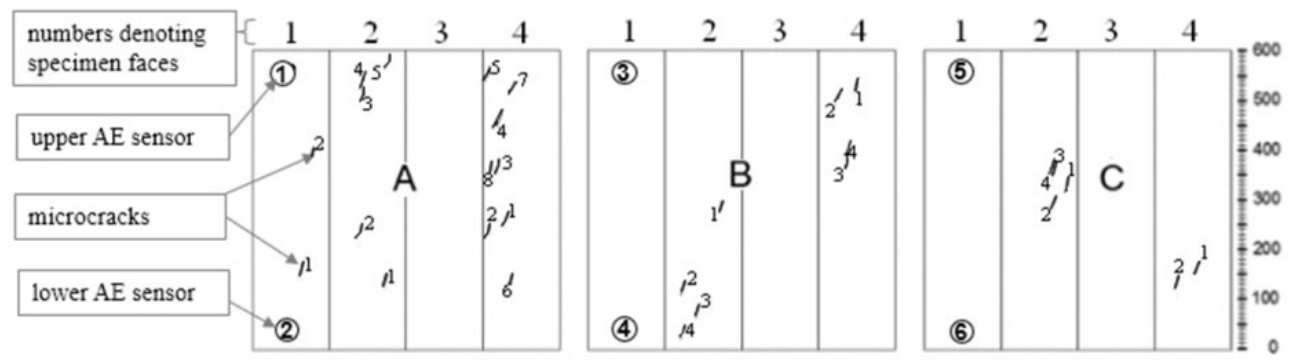

Fig. 9. Image of side surface microcracks, specimens A, B and C in the B6 series. 


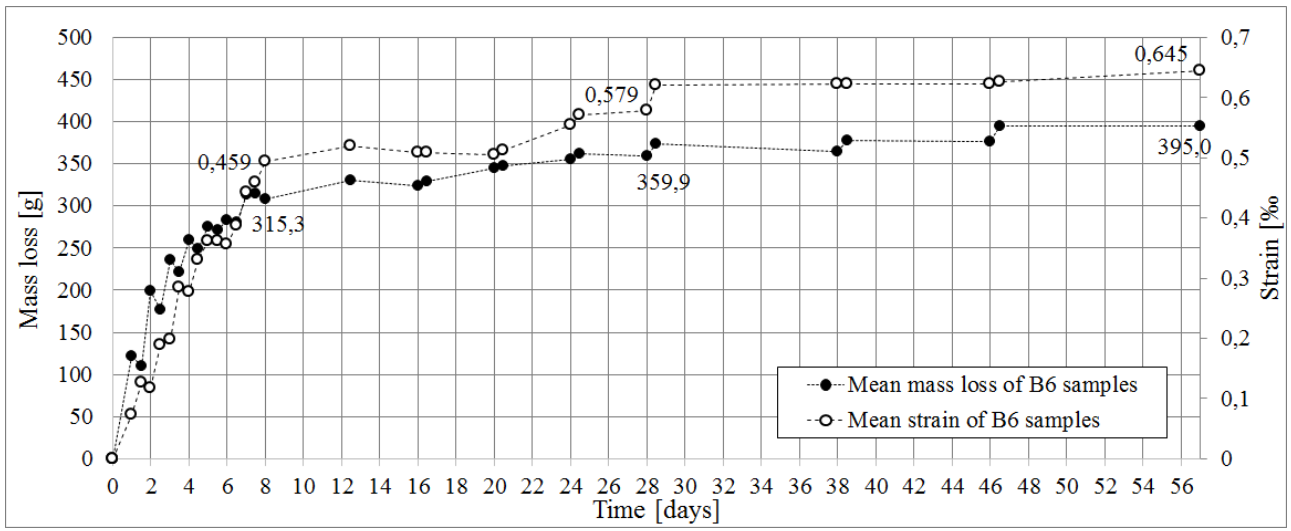

Fig. 10. Diagram of average mass loss and average strain in $B 6$ concrete specimens (A, B, C).

In the figure 10 shown the course of strains and mass loss of B6 samples. The highest increase of values was observed in the first week of the study. After this day values began to stabilize until the end of the test, excluding days 24 and 28 in which a significant increase in strain was observed.

Table 5. Average values measured in B6 concrete during the day in a particular stage of the study.

\begin{tabular}{|c|l|l|l|l|}
\hline $\begin{array}{c}\text { Concrete } \\
\text { series }\end{array}$ & $\begin{array}{l}\text { Parameter of test [average values measured } \\
\text { during a day] }\end{array}$ & $1-8$ days & $8-28$ days & $28-57$ days \\
\hline \multirow{2}{*}{ B6 } & Strain [\%o/day] & 0.063 & 0.006 & 0.002 \\
\cline { 2 - 5 } & Mass loss [g/day] & 44.00 & 2.12 & 1.21 \\
\hline
\end{tabular}

\subsection{Analysis of the influence of maturation conditions on the course of destructive processes}

In order to determine the impact of maturing conditions on the course of destructive processes in non-loaded concrete, the results recorded in B5 concrete specimens were compared with the results obtained from test of B6 concrete specimens.

Registered AE signals (destructive processes) are distinguished by 12 parameters, including signal energy. Figure 11 shows values of unit energy of Class 1, 2 and 3 for B5 and B6 concrete series computed as a ratio of energy to number of signals recorded during 12 hours periods. Broken lines marked mean unit energy calculated as the energy sum from all signals of given Class (1, 2 or 3) recorded for each concrete series (B5 or B6) during 28 days divided by number of signals. 

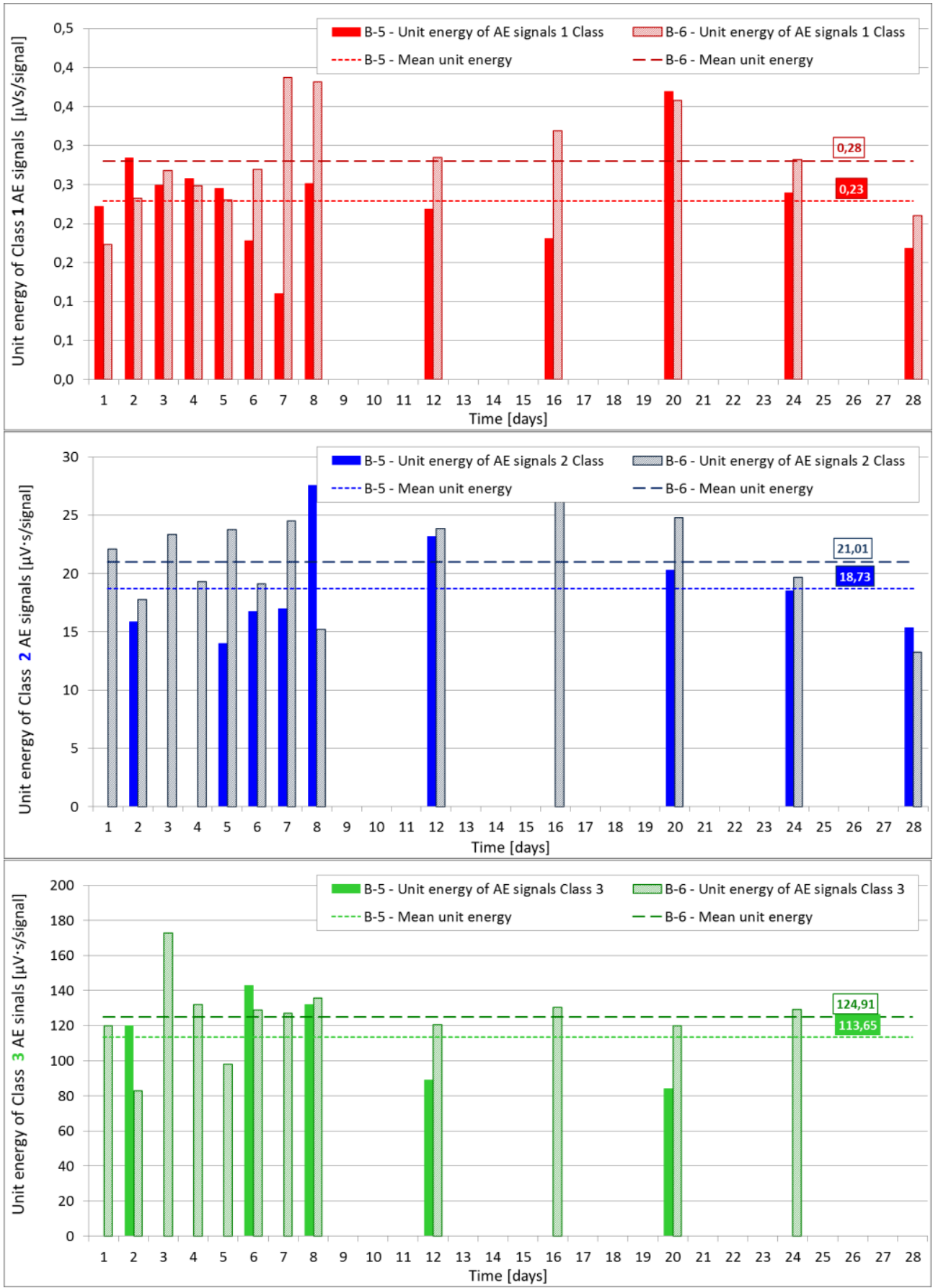

Fig. 11. Unit energy of Classes 1,2,3 AE signals for B5 and B6 concrete specimens.

During first 28 days of test the higher unit energy of signal Classes 1,2 and 3 was recorded in B6 concrete (maturing under variable temperature conditions) compared to B5 concrete (maturing under constant temperature conditions).

In table 6 results of test analyzes have been compiled. 
Table 6. Comparison of the results of the number and unit energy of AE signals.

\begin{tabular}{|l|c|c|c|c|c|c|}
\hline Concrete series & \multicolumn{3}{|c|}{ B5 } & \multicolumn{3}{c|}{ B6 } \\
\hline $\begin{array}{l}\text { Average numbers of AE } \\
\text { signals (destructive processes) }\end{array}$ & 4084 & 11 & 2 & 5588 & 39 & 6 \\
\hline Unit energy of signals & 0.23 & 18.99 & 113.65 & 0.28 & 21.01 & 124.91 \\
\hline Time of occurrence of signals & $>57$ & 28 & 20 & $>57$ & $>57$ & 24 \\
\hline
\end{tabular}

The results obtained for series B5 concrete hardening at a constant temperature of $22^{\circ} \mathrm{C}$ (Fig. 5) and for series B6 concrete (Fig. 8) hardening under varied temperature formed a basis for the following conclusions concerning the concrete produced with basalt aggregate and blast furnace cement, not subjected to curing after demoulding:

- The measurements carried out within the 57-day period indicate that cyclically varied curing conditions increased the number of microcracks forming in the cement paste by about $37 \%$. The number of propagating internal microcracks and microcracks forming on the surface of concrete more than tripled.

- Curing conditions limited the duration of damage processes in concrete; when curing under constant temperature, the microcracks initiating in the cement paste did not fade after 57 days; the propagation of internal microcracks faded out after 28 days; the microcracks forming on the surface of concrete members faded out after 20 days. In the concrete cured under cyclically varied temperature conditions, all these processes (signals corresponding to damage process I, II and III) did not fade out within the 57-day monitoring period.

\section{Conclusions}

As shown by the results of tests and analyses performed with the acoustic emission method temperature variation has a profound effect on damage processes in non-loaded concrete:

- increase the level of damage processes; microcracks generated at variable temperature were characterized by a higher level of unit energy,

- affect the number of damage processes in concrete; the cyclically varied temperature contributed to increased number of microcracks forming in the cement paste, increased propagation of internal microcracks and increased number of microcracks forming on the concrete surface,

- affect the duration of damage processes in non-loaded concrete.

Results shown that AE method can be used for the study and analyze of destructive processes in non-loaded concrete. 


\section{References}

1. A.M. Neville, Properties of concrete (Pearson Education Limited, United Kingdom, 2012)

2. Concise Statistical Yearbook of Poland, 26, Warsaw (2018) [in Polish]

3. D. Baranowski, Słupskie Prace Geograficzne, 2, pp. 171-181 (2005) [in Polish]

4. Online: http://www.guinnessworldrecords.com/world-records/greatest-temperaturerange-in-day

5. K. Flaga, Inżynieria i Budownictwo, 6, pp. 315-322 (1995) [in Polish]

6. W. Kurdowski, Cement and Concrete Chemistry, (Springer, London, 2014)

7. A.M. Brandt, D. Jóźwiak-Niedźwiedzka, ACEM, 1(1), pp. 1-21 (2012)

8. A. Mohan, S. Poobal, Alexandria Eng. J., 57(2), pp. 787-798 (2017)

9. Z. Wu, H.S. Wong, N.R. Buenfeld, Cem. Conc. Res., 98, pp. 136-154 (2017)

10. J. Bisschop J., J.G.M. van Mier, Cem. Conc. Res., 32, pp. 279-287 (2002)

11. J. Hoła, K. Schabowicz, ACME, 10(3), pp. 5-18 (2010)

12. Z. Ranachowski, Roads and Bridges, 2, pp. 65-87 (2012)

13. A. Garbacz, Nieniszczace badania betonopodobnych kompozytów polimerowych za pomoca fal sprężystych - ocena skuteczności napraw (Oficyna Wydawnicza Politechniki Warszawskiej, Warszawa, 2007) [in Polish]

14. T. Chariton, B. Kim, W.J. Weiss, Using Passive Acoustic Energy to quantify cracking in volumetrically restrained cementitous systems (Proceedings of the Conference: American Society of Civil Engineers - Engineering Mechanics Division, New York, 2002)

15. J. Bisschop, J.G.M. van Mier, HERON, 47(3), pp. 163-184 (2002)

16. T. Watanabe, T. Ohno, C. Hashimoto, Conc. Res. Lett, 2(3), pp. 290-294 (2011)

17. G. Świt, Analiza procesów destrukcyjnych $w$ obiektach mostowych $z$ belek strunobetonowych z wykorzystaniem zjawiska emisji akustycznej (Kielce University of Technology, Kielce, 2011) [in Polish]

18. B. Goszczyńska, ACME, 14(2), pp. 134-143 (2014)

19. B. Goszczyńska, G. Świt, W. Trąmpczyński, A. Krampikowska, J. Tworzewska, and P. Tworzewski, ACME, 12(3), pp. 23-28 (2012)

20. B. Goszczyńska, G. Świt, W. Trąmpczyński, Bulletin of the Polish Academy of Sciences: Technical Sciences, 63(1), pp. 55-63 (2015)

21. M. Bacharz, B. Goszczyńska, W. Trąmpczyński, Procedia Eng. 108, pp. 245-253 (2015) 